\title{
The Influence of Leadership Style on Job Satisfaction among Nurses
}

\author{
Abd Rahman Ahmad ${ }^{1}$, Mohd Nazir Mohd Adi ${ }^{1}$, Haris Md. Noor ${ }^{1}$, Abdul Ghafar Abdul Rahman ${ }^{1} \&$ Tan \\ Yushuang $^{1}$ \\ ${ }^{1}$ Faculty of Technology Management and Business, Universiti Tun Hussein Onn Malaysia, Malaysia \\ Correspondence: Abd Rahman Ahmad, Faculty of Technology Management and Business, Universiti Tun \\ Hussein Onn Malaysia, 86400 Batu Pahat, Johor, Malaysia. Tel: 60-7453-3952. E-mail: arahman@uthm.edu.my
}

Received: April 4, 2013 Accepted: May 20, 2013 Online Published: June 28, 2013

doi:10.5539/ass.v9n9p172 URL: http://dx.doi.org/10.5539/ass.v9n9p172

\begin{abstract}
Nurses roles and responsibilities contribute to the quality improvement of health care services in Malaysia. Previous research has shown that leaders play an important role in enhancing job satisfaction among the nurses. Indeed, the transformational and transactional leadership was found to be the most efficient influence among the leadership style in attaining job satisfaction. The objective of this study is to investigate the transformational and transactional leadership styles that might contribute to the job satisfaction among nurses. Survey questionnaires were used in this study as a main method for data collection. Results indicated that the transformational have more contribution towards job satisfaction compare to transactional leadership style. Based on the results, this study also includes the recommendation of future research that might be relevant to be further explored.
\end{abstract}

Keywords: leadership, transformational, transactional, job satisfaction and nurses

\section{Introduction}

In order to implement the health care reforms the nurses' quality services provided to the patients need to be further enhanced (Al-Ahmadi, 2008). This is very challenging due to the factors that the turnover of nurses working in government and private sectors is very high (Charka, 2009). The situation has become more critical when those experiences and highly trained staff leave the organization. There are several factors that contributed to the high turnover in this job title and one of the reasons is the job satisfaction. Lim (2007) further supports that job satisfactions cause the high turnover rates of staff in the healthcare industry. Indeed, previous research shows the nurses job lead to job stress, burnout and absenteeism. A good leadership style might contribute to increase in job satisfaction among employees (Rad \& Yarmohammadian, 2006; Limsila \& Ogunlana, 2007). Powell et. al., (2008) argued that transformational and transactional leadership are the main factors contributing to the job satisfaction.

Research in the area of leadership has been widely studied across all countries and most of the common leadership style includes: (1) autocratic, (2) bureaucratic, (3) laissez-faire, (4) charismatic, (5) democratic, participative, (6) situational, (7) transactional, and (8) transformational (Mosadeghrad, 2003). However, Rad and Yarmohammadian (2006) pointed out that different situation needs different leadership style. Therefore, leaders might implement different types of skills in order to increase job satisfaction among the employees.

\section{Literature Review}

Lo et al. (2009) argued that the leader plays an important role in delivering the responsibility rather than the focused on the authority and command when dealing with the subordinates. Besides that, leaders attitudes, behaviors, characteristics and skills might contribute to the good leadership style in the organization (Mosadeghrad, 2003). Indeed, a good leader could lead their employees to perform at the highest capability (Rad \& Yarmohammadium, 2006). These leaders should have the capability to operate with integrity, honest, efficiently, and communicate clearly with employees (Aronson et. al., 2003). Effective leadership style might contribute to the success in completing task given (Gharehbaghi \& McManus, 2003). Limsila and Ogunlana (2007) indicated that an appropriate leadership style leads to employee satisfaction and it is a good indicator to prove that a better style might lead employee to work effectively (Likhitwonnawut, 1996). Here, leaders should be able to communicate the values, vision and mission of their organization in order to motivate the employees (Borkowski et. al., 2011). Besides that, a leader is also a person who has the ability to guide their employees and direct their behavior (McEachen \& Keogh, 2007). 
Lo et. al., (2009) argued that transactional leadership demonstrated to be more efficient in obligation to change rather than those that have transformational leadership style. Transformational leadership style employees' performances with their organizational mission, as for transactional leadership, they can create a compliant workforce (Nancy et. al., 2011). Transformational is more to building relationship between employees and employers and transactional is more to task orientation where completing task is more important (Limsila \& Ogunalana, 2007).

\subsection{Transformational Leadership}

Krishnan (2005) argues that the transformational leadership style enhances the organization employees towards achieving more rather than just what they had planned. Here, this leadership style leads to the process of transforming the followers' emotion, value, and goals for the specific performance based on their talent (Northouse, 2009). Tales (2010) classify the transformational leadership under five different styles as follows:

1) Intellectual stimulation

This style of transformational leadership encourages employees' creativity and innovation with a certain limit and solve with new ways for older cases.

2) Individual consideration

Encouragement and support build from the relationship between employee and employer such as a mentor or coach in the process of teaching and sharing ideas or knowledge.

3) Inspirational motivation

A clear vision, meaning of task and a challenging task are being given by the leader to the employee.

4) Idealized influence

Leaders are the role models who take the initiative, understand, and have the determination in completing tasks.

5) Attributed charisma

The way a charismatic leader act and speak can convince their followers to respect and admire them.

\subsection{Transactional Leadership}

Burns (1978) defined the transactional leadership style that comprises motivation and directing to achieving followers self-interest through rewards and punishment for the exchange. This leadership style is very useful when the organization is in a stable position and the learning objectives aim to refine and restore balance (Bucic et. al., 2010). A transactional leader could increase the employees' performance especially when employees' performances are being measured quantitatively and reward or punishments are being given fairly. The Transactional leadership style is very useful when the organization is in a stable position and the learning objectives aim to refine and restore balance (Bucic et. al., 2010).

Tale (2010) indicated that there are three dimensions of transactional leadership:

1) Contingent rewards

There is an exchange of reward system occur between employers and employees. Employees are being promised to gain something from completing a task

2) Active management-by-exception

Is where leaders examine and monitor for any error or mistakes happen and apply for corrective action once the problems happen.

3) Passive management-by-exception

This type of leader takes action only after mistake occurred. It is systematic and not advisable as leaders not only intervening when problems happen.

\subsection{Job Satisfaction}

Job satisfaction is being defined as how much a person like a their job or the task they are doing, job satisfaction does not related to how a work can be done well, or how much effort an employee have put into it (Hughes et al., 2006). Job satisfaction could lead the employees to be more productive, innovative, and dedicated to maintaining the quality services given to the patient. Lim (2007) pointed out that the job satisfaction have been extensively studied as it gives a big impact in affecting productivity and service delivery especially in health care where nurses are the front line to the quality services. 


\subsection{Differentiation between Two Leaderships Style}

Transformational leadership style is more focused to build the relationship between employees and employers and transactions are more to task orientation where completing task is more important (Limsila \& Ogunalana, 2007). Transformational leader's emphasis on team building that encourage employee to perform by giving their own ideas, encourage their creativity, contribute their personal knowledge but transactional take more attention in understanding how organization process is functioning, the level of the organization, and does not consider employees' learning ability (Vera \& Crossan, 2004). According to Northouse (2009), transformational is more to create a relationship that can raise the employees' motivation and morality, leaders in transformational styles is more to help employees to show their full potential, however, for transactional leadership it is more to exchange between the leaders and the employees which being described as the bulk of leadership models.

\subsection{Factors Lead to Job Satisfaction}

Rad and Yarmohammadian (2006) identified some of the factors that might contribute to the job satisfaction that consist of: wages, benefits, accomplishment, independence, acknowledgment, communication, working job conditions, job importance, co-workers, professionalism, organizational climate, relationships, working for a reputable agency, supervisor support, positive, job security, workplace flexibility, team environment and genetic factors. Meanwhile, Vigoda and Cohen (2003) pointed out that job satisfaction and leadership style could improve the relationship between employees and employers. Therefore, it is clearly indicated that leadership styles have influence to the job satisfaction among employees. However, in this study the focus is between these two variables is seen from the point of health care industry. This is due to the factors that the healthcare industry in Malaysia is facing problems where they are having shortage nurses and high turnovers due to the work load (Lim, 2007). Previous research from Lorber and Skela Savic (2012) shows that the higher nurse job satisfaction was also being influenced with the leadership style. Indeed, Top et. al., (2012) argued that there is a need to further investigate the job satisfaction and leadership style in health organizations. Therefore, based on the above argument the research question of this study is: in what way the transformational and transactional leadership factors affected the nurses' job satisfaction? The objective of the study is to identify the transformational and transactional leadership characteristics that might contribute to the job satisfaction.

\section{Methodology}

The research design of the study is shown in the figure below.

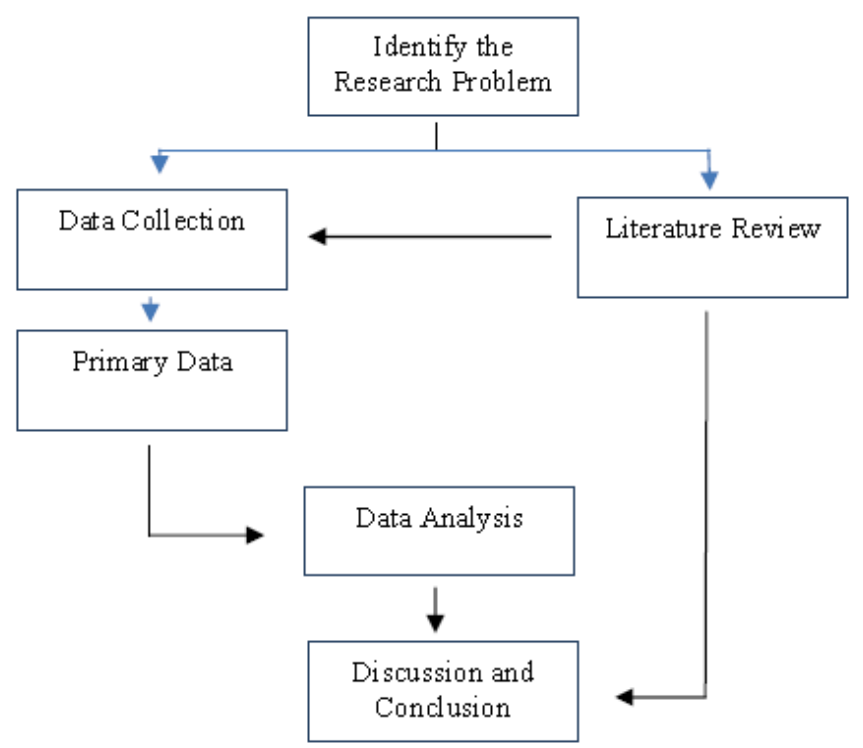

Figure 1. The research design

The questionnaire used in this study is being prepared in Likert Scale, and the questionnaire is being named as the Multifactor Leadership Questionnaire (MLQ). Meanwhile, Work Quality Index (WQI) is used to measure the job satisfaction. MLQ was adopted to evaluate the behavior of leaders they feel that are best match their satisfaction. Gadot (2006) pointed out that MLQ could be used to evaluate the types of behaviors for the most preferred leader in the organization that are best match their satisfaction. Indeed, it is being revised many times 
to measure the extent to which leaders demonstrate behaviors' associated with transformational and transactional leadership (Ramey, 2002). In this study, the questionnaire is being modified to include questions that related to the context of the study. It is measured using a set of Likert scale $(0=$ not at all, $1=$ once in a while, $2=$ sometimes, 3 = fairly often and 4= frequently, if not always). Meanwhile, the Work Quality Index with Likert scale is also being used to identify nurses' job satisfaction. The questions were also developed based on a five point Likert scale $(1=$ strongly dissatisfied, $2=$ dissatisfied, $3=$ neutral, $4=$ satisfied and $5=$ strongly satisfied $)$. Data were then being analysed using SPSS software.

Descriptive statistics were used to identify the characteristics of the distribution of scores the data have been collected. Results indicated that most of the variables are normally distributed. Results from Shapiro-Wilk shows that all of the variables have the significant value of more than 0.05 . Here, Pearson Correlation was used to investigate the relationship between job satisfaction and leadership style.

Table 1. Reliability analysis

\begin{tabular}{lll}
\hline Test & Cronbach's Alpha & N of Items \\
\hline Job Satisfaction & 0.97 & 37 \\
Leadership Style & 0.95 & 28 \\
\hline
\end{tabular}

The Cronbach's alpha for both job satisfaction and leadership style was at 0.97 and 0.950 as indicate in the table below. Results indicated the tests are reliable and none of the items used in the pilot test were taken out in the final study.

\section{Results and Discussion}

Table below indicated the respondents' background. Of the 115 questionnaires distributed to the respondents only 33 (28\%) were returned and used for data analysis.

Table 2. Respondents background

\begin{tabular}{llll}
\hline Characteristics & Category & Frequency & Percentage \\
\hline Gender & Female & 29 & 87.9 \\
& Male & 4 & 12.1 \\
Age & $18-25$ & 33 & 100.0 \\
& $26-35$ & 15 & 45.5 \\
& $36-45$ & 13 & 39.4 \\
& $>56$ & 3 & 9.1 \\
Ethnicity & Total & 2 & 6.1 \\
& Malay & 33 & 100.0 \\
& Chinese & 24 & 72.7 \\
Education Level & Indian & 5 & 15.2 \\
& Total & 4 & 12.1 \\
& Nursing Diploma & 33 & 100.0 \\
& Associates Degree & 29 & 87.9 \\
Others & 1 & 3.0 \\
Torking experience & Total & 3 & 9.1 \\
& Less than one year & 33 & 100.0 \\
& $1-2$ years & 7 & 21.2 \\
& $3-5$ years & 10 & 30.3 \\
& 6-10 years & 8 & 24.2 \\
& $11-15$ years & 3 & 9.1 \\
& $16-20$ years & 2 & 6.1 \\
& $>20$ years & 1 & 3.0 \\
Total & 2 & 6.1 \\
& & 33 & 100 \\
\hline
\end{tabular}


Results show that majority of the respondents are female nurses $(87.9 \%)$ and only 12.1 percent male nurses. Meanwhile, 45.5 per cent of the respondents between age 18 to 25 years old and another 39.4 percent of them between age 26 to 35 years old. Another 9.1 per cent of the respondents between 36 to 45 years old and the remaining 6.1 per cent of respondents over 56 years old. Meanwhile, according to ethnic groups, 72.7 per cent of the respondents are Malay, 15.2 per cent are Chinese and only 12.1 are Indian. In relation to education level, the majority (87.9\%) of the respondents had Nursing Diploma and follow with 3 percent of them had Associated Degree and others $(9.1 \%)$ qualifications. This study indicated that the majority of the respondents have the working experiences of 1 to 2 years. Results also showed that the respondents that have 3 to 5 years working experience were only 24.2 percent.

\subsection{Mean Analysis}

As shown in Table 3, transformational leadership have higher mean compare to transactional leadership which means that transformational leadership style is more acceptable for nurses compare to transactional leadership style.

Table 3. Mean results

\begin{tabular}{lcc}
\hline & Mean & Standard Deviation \\
\hline Transformational Leadership & 3.4516 & 0.78238 \\
Transactional Leadership & 2.9936 & 0.89755 \\
\hline
\end{tabular}

This result might be significant due to the factors that transformational leadership has the ability to encourage the employees towards achieving more rather than just what they had planned (Krishnan, 2005). Transformational leadership are being said as a leader who take more attention on charismatic and affective elements of leadership so it is best fit the condition of today's organization. It is a process of changes and transform of people which leader takes into account the emotion of employees, values, ethnicity, standards and long term goals. It can be used broadly in an organization whether to influence employees or even the whole organization. Those who perform transformational leadership have a strong internal value and ideals that support the idea or give chances for their employees themselves to perform their talent (Northouse, 2009).

\subsection{Correlation Results}

Correlation tests indicate the strength and direction of the relationship between the leadership style and job satisfaction. Table 4 below depicts the degree of relationship between these two variables (job satisfaction and transformational leadership style).

Table 4. Correlations among job satisfaction and transformational leadership

\begin{tabular}{lcc}
\hline & Job Satisfaction & Transformational Leadership \\
\hline Job Satisfaction & --- & \\
Transformational Leadership & $0.642^{* *}$ & --- \\
\hline
\end{tabular}

$* * \mathrm{p}<0.05$

As indicated in the table above, the correlation between job satisfaction and transformational leadership style were highly significant $(\mathrm{p}=0.000, \mathrm{r}=0$. 64). There was a significant correlations reported indicate that there is a relationship between transformational leadership and job satisfaction.

Table 5. Correlations among job satisfaction and transactional leadership

\begin{tabular}{lcc}
\hline & Job Satisfaction & Transactional Leadership \\
\hline Job Satisfaction & --- & \\
Transactional Leadership & $0.392 * *$ & -- \\
\hline$* * \mathrm{p}<0.05$ & &
\end{tabular}


Meanwhile, Table 5 demonstrated results that are proving to be a significant relationship between transactional leadership and job satisfaction with the $r$ value of $0.392(p=0.000)$ indicates a weak relationship between transactional leadership and job satisfaction. Transformational leadership is suitable to use when the organization faces a dynamic, evolving situation and organizational learning is required to be adaptive and progressive (Bucic et al., 2010).

Results indicated that there are strong relationships between job satisfaction and transformational leadership comparable to transactional leadership. There is also a different effect between transformational leadership and transactional leadership on job satisfaction. Transformational leadership has higher ratio and beta that show higher influence on job satisfaction compare to transactional leadership. Here, this result further supports the study from Tale (2010), where there are relationship between transformational leadership and transactional leadership on job satisfaction. However, transformational leadership is the dominant leadership style that can affect nurses' job satisfaction. In another previous study, both leadership styles had also been shown have an effect on job satisfaction but according to the analysis being done, the transformational leadership style was found to behave higher leadership outcome compare to transactional leadership (Limsila \& Ogunlana, 2007).

Employees are one of the most important assets for an organization. Their role is vital to the organization's success. In the healthcare industry for example nurses play an important in providing quality services to the patient and promote better lifestyle. Thus, it is important for the organization to ensure that they have high job satisfaction while providing the services to the patient. Here, it is very important that nurses working under a condition which are not highly stress since that they interact with human feelings and problems at most of the time. As stated before, there are lots of factors that contributed to the job satisfaction. However, in this study the focus on leadership style has indicated that leadership style is also contributing to nurse job satisfaction.

\subsection{Recommendation for Future Research}

This study can be further enhanced at other area such as in hotel management, banking sector, government department and other organizations in order to further analyse the relationship between leadership style and job satisfaction. The study also can be further explored to include the other factors that might contribute to the job satisfactions among employees.

\section{Conclusion}

This research study is to find on the leadership style that can affect nurses' job satisfaction. The findings of this study have shown that factors that can affect nurses' job satisfaction are transformational leadership. The factors of transformational leadership and transactional leadership factors that can affect nurses' job satisfaction.

\section{References}

Al-Ahmadi, H. (2009). Factors affecting performance of hospital nurses in Riyadh Region, Saudi Arabia. International Journal of Health Care Quality Assurance, 22(1), 40-54. http://dx.doi.org/10.1108/09526860910927943

Aronson, K. R., Sieveking, N., Laurenceau, J. P., \& Bellet, W. (2003). Job satisfaction of psychiatric hospital employees: a new measure of an old concern. Administer Policy Mental Health, 30(5), 437-452. http://dx.doi.org/10.1023/A:1024645731339

Borkowski, N., Deckard, G., Weber, M., Padron, M. A., \& Luongo, S. (2011). Leadership development initiatives underlie individual and system performance in a US public healthcare delivery system.

Bucic, T., Robinson, L., \& Ramburuth, P. (2010). Effects of leadership style on team learning. Journal of Workplace Learning, 22(4), 228-248. http://dx.doi.org/10.1108/13665621011040680

Bums, J. M. (1978). Leadership. Harper \& Row, New York, NY.

Charka, T. (2008). Healthcare Sector in Malaysia. Retrieved August 10, 2011, from http://www.tradechakra.com/economy/malaysia/health-sector-in-malaysia-211.php

Cohen, A., \& Golan, R. (2007). Predicting absenteeism and turnover intentions by past absenteeism and work attitudes An empirical examination of female employees in long term nursing care facilities. Career Development International, 12(5), 416-432. http://dx.doi.org/10.1108/13620430710773745

Gadot, E. V. (2007). Leadership style, organizational politics and employees' performance: An empirical examination of two competing models. Personal Review, 36(5), 661-683. http://dx.doi.org/10.1108/00483480710773981

Gharehbaghi, K., \& McManus, K. (2003). Effective construction management. Leadership and Management in 
Engineering, 3(1), 54-55. http://dx.doi.org/10.1061/(ASCE)1532-6748(2003)3:1(54)

Grohar-Murray, M. E., \& Dicroce, H. R. (1997). Leadership and Management in Nursing (2nd ed.). United States of America: Appleton \& Lange.

Hayes, L. J., O’Brien-Pallas, L., Duffied, C., Shamian, J., Buchan, J., Hughes, F. ... Stone, P. W. (2006). Nurse turnover: a literature review. International Journal of Nursing Studies, 43, 237-263. http://dx.doi.org/10.1016/j.jinurstu.2005.02.007

Hugnes, R. L., Gonnett, R. C., \& Curphy, G. J. (2006). Leadership, Enhancing the Lessons of Experience (5th ed.). United States: McGraw Hill.

Krishnan, V. R. (2005). Transformational leadership and outcomes: role of relationship duration. Leadership and Organization Journal, 26(5-6), 442-457. http://dx.doi.org/10.1108/01437730510617654

Likhitwonnawut, A. (1996), Leadership styles of construction managers and their impact on project performance. School of Civil Engineering, Asian Institute of Technology, Klong Luang: Master Thesis.

Lim, B. E. (2007). Study on the Job Satisfaction and Burnout among Medical Social Workers in Government Hospital in Malaysia. Universiti Sains Malaysia. Master of Social Work.

Limsila, K., \& Ogunlana, S. O. (2008). Performance and leadership outcome correlates of leadership style and subordinate commitment. Engineering, Construction and Architectural Management, 15(2), 164-184. http://dx.doi.org/10.1108/09699980810852682

Lo, M. C., Ramayah, T., De Run, E. C., \& Voon, M. L. (2009). "New Leadership", Leader-Member Exchange and Commitment to Change: The Case of Higher Education in Malaysia. Proceedings of World Academy of Science, Engineering and Technology, 41, pp. 1-7.

Lorber, M., \& Skela Savič, B. (2012). Job satisfaction of nurses and identifying factors of job satisfaction in Slovenian Hospitals. Croatian Medical Journal, 53(3), 263-270. http://dx.doi.org/10.3325/cmj.2012.53.263

McEachen, I., \& Keogh, J. (2007). Nurse Management. United States of America: McGrawHill.

Mosadeghrad, A. M. (2003). The role of participative management (suggestion system) in hospital effectiveness and efficiency. Research in Medical Sciences, 8(3), 85-89.

Northouse, P. G. (2009). Leadership, Theory and Practice (5th ed.). United States of America: Sage.

Powell, G. N., Butterfield, D. A., \& Bartol, K. M. (2008). Leader evaluations: A new female advantage? Gender Management: An International Journal, 23(3), 156-174. http://dx.doi.org/10.1108/17542410810866926

Price, J. L., \& Mueller, C. (1981). A casual model of turnover for nurses. Academy of Management Journal, 24, 543-565. http://dx.doi.org/10.2307/255574

Rad, A. M. M., \& Yarmohammadian, M. H. (2006). A study of relationship between managers' leadership style and employees' job satisfaction. Leadership in Health Services, 19(2), 11-28. http://dx.doi.org/10.1108/13660750610665008

Tale, S. M. (2010). Leadership Style and Job Satisfaction among Nurses. Master of Human Resource Management University Utara Malaysia.

Top, M., Tarcan, M., Tekingündüz, S., \& Hikmet, N. (2012). An analysis of relationships among transformational leadership, job satisfaction, organizational commitment and organizational trust in two Turkish hospitals. The International journal of health planning and management. http://dx.doi.org/10.1002/hpm.2154

Vera, D., \& Crossan, M. (2004). Strategic leadership and organizational learning. Academy of Management Review, 29(2), 222-240.

Vigoda, E., \& Cohen, A. (2003). Work Congruence and Excellence in Human Resource Management. Empirical evidence from the Israel non-profit sector. Public Personnel Administration. pp. 192-216.

\section{Copyrights}

Copyright for this article is retained by the author(s), with first publication rights granted to the journal.

This is an open-access article distributed under the terms and conditions of the Creative Commons Attribution license (http://creativecommons.org/licenses/by/3.0/). 